\title{
Purification and characterization of diacetyl-reducing enzymes from Staphylococcus aureus
}

\author{
Isabel VIDAL, Josefa GONZÁLEZ, Ana BERNARDO and Roberto MARTÍN* \\ Facultad de Veterinaria, Universidad de León, Campus de Vegazana, 24007 León, Spain
}

\begin{abstract}
A method was developed to purify diacetyl-reducing enzymes from Staphylococcus aureus. Two enzymes capable of catalysing diacetyl reduction were isolated, neither of which turned out to be a specific diacetyl reductase. One of them is a lactate dehydrogenase similar to the one from Staphylococcus epidermidis, which accepts diacetyl, although poorly. The other one uses as coenzyme $\beta$-NAD and reduces uncharged $\alpha$ dicarbonyls with more than three carbon atoms (especially the $\alpha$-diketones diacetyl and pentane-2,3-dione), producing the $\mathrm{L}(+)$ form of the corresponding $\alpha$-hydroxycarbonyls. This enzyme has an $M_{\mathrm{r}}$ of 68000 and is, most probably, a monomer. Its optimum $\mathrm{pH}$ is 6.0. Its shows a high affinity for NADH and a rather low one for diacetyl, which, at least in vitro, does not seem to be as good a substrate as pentane-2,3-dione. We propose for it the systematic name $\mathrm{L}-\alpha$-hydroxyketone: $\mathrm{NAD}^{+}$oxidoreductase and the recommended name of $\alpha$-diketone reductase (NAD). We also suggest that the diacetyl reductase entry in the I.U.B. classification be suppressed.
\end{abstract}

\section{INTRODUCTION}

Diacetyl reductase (acetoin: $\mathrm{NAD}^{+}$oxidoreductase) was first described in extracts of Staphylococcus aureus, by Strecker \& Harary (1954). These authors partially purified this enzyme and proved that it catalyses the reduction of diacetyl to acetoin using NADH as hydrogen donor. The 1984 edition of I.U.B. Enzyme Nomenclature includes this reductase with the number EC 1.1.1.5, on the basis of the report by Strecker \& Harary (1954) and of a study performed by our group with pigeon liver extracts (Diez et al., 1974). However, we have since shown (Bernardo et al., 1984) that the pigeon enzyme is not properly described by the EC 1.1.1.5 entry. In fact, it is a reductase of the same kind as the one isolated from bovine liver by Provecho et al. (1984), for which the name of $\alpha$-dicarbonyl reductase [ $L-\alpha$-hydroxycarbonyl: NAD $(\mathrm{P})^{+}$oxidoreductase, EC 1.1.1.-] has been proposed: it reduces uncharged $\alpha$-dicarbonyls with more that three carbon atoms using either NADPH or NADH.

Therefore the diacetyl reductase entry in the I.U.B. classification is supported nowadays only by the data on the Staph. aureus enzyme obtained by Strecker \& Harary (1954). However, the specificity of this enzyme has never been studied, and other properties that would help to characterize it, such as its $M_{\mathrm{r}}$ and kinetic behaviour, are also unknown. Several enzymes capable of reducing diacetyl without being specific diacetyl reductases have been reported (Bryn et al., 1971; Bernardo et al., 1981; Van den Berg et al., 1983; Provecho et al., 1984). That studied by Strecker \& Harary (1954) could be any one of them.

The present paper describes a new purification procedure for the diacetyl-reducing enzymes from Staph. aureus and some of their properties related to their characterization. It also discusses, in view of the results obtained and previous reports, whether the diacetyl reductase entry in the I.U.B. classification could be kept or should be modified.

\section{EXPERIMENTAL}

\section{Materials}

NADPH, NADH and NAD $^{+}$were obtained from Boehringer; diacetyl, acetaldehyde, acetone, butan-2one, glyoxal, hexanal, glyoxylic acid and pyruvic acid were from Merck; $\alpha$-NADH, methylglyoxal, methyl pyruvate, ethyl pyruvate, glycolaldehyde and lactate dehydrogenase from Staphylococcus epidermidis were from Sigma Chemical Co.; pentan-3-one and ethyl acetoacetate were from Fluka; pentane-2,4-dione and hexane-2,5-dione were from BDH Chemicals; 2-oxoglutaric acid was from Schuchart; pentane-2,3-dione was from Eastman. Acetoin (Fluka) was purified by the procedure described by Burgos \& Martín (1972) to remove traces of diacetyl.

\section{Bacterial strains}

As enzyme source, 44 Staph. aureus strains from the American Type Culture Collection, the National Collection of Type Cultures and the Food Research Institute in Madison (WI, U.S.A.) were tested. The N.C.T.C. 10652A strain was the final choice.

Cells were grown in static culture, at $30^{\circ} \mathrm{C}$, in the medium proposed by Strecker \& Ochoa (1954).

\section{Methods}

Protein was determined by the Warburg \& Christian (1941) procedure, except in crude extracts, where it was measured by the biuret method (Chance \& Redfearn, 1961). Diacetyl was determined by the Owades \& Jakovac method (Pack et al., 1964), and acetoin by the procedure of Fuertes et al. (1977).

Enzyme assays were performed at $25^{\circ} \mathrm{C}$, by monitoring the decrease in $A_{340}$ (Strecker \& Harary, 1954). One unit is defined as the enzyme amount that reduces $1 \mu \mathrm{mol}$ of diacetyl/min under the standard conditions of analysis.

Polyacrylamide-gel electrophoresis was performed as previously described (Provecho et al., 1984). The Fenner

\footnotetext{
* To whom correspondence should be addressed.
} 
Table 1. Purification of diacetyl-reducing enzymes from Staph. aureus

For experimental details see the text. Average results from four batches, each starting with $18 \mathrm{~g}$ of cells, are shown.

\begin{tabular}{lcccccc}
\hline Purification step & Volume & $\begin{array}{c}\text { Total } \\
\text { protein } \\
(\mathrm{mg})\end{array}$ & $\begin{array}{c}\text { Total } \\
\text { activity } \\
\text { (units) }\end{array}$ & $\begin{array}{c}\text { Sp. activity Purification } \\
\text { (units/mg) }\end{array}$ & $\begin{array}{c}\text { Yield } \\
(\%)\end{array}$ \\
\hline $\begin{array}{l}\text { 1. Extract } \\
\text { 2. DEAE-cellulose chromatography }\end{array}$ & 40 & 810 & 400 & 0.5 & - & - \\
$\begin{array}{l}\text { 3. Sephadex G-200 gel filtration } \\
\text { 4. Hydroxyapatite chromatography }\end{array}$ & 7.5 & 135 & 270 & 2 & 4 & 70 \\
$\quad \begin{array}{l}\text { Enzyme A } \\
\text { Enzyme B }\end{array}$ & 3 & 16.8 & 100 & 6 & 12 & 25 \\
\end{tabular}

method (Fenner et al., 1974) was followed to stain protein, and enzyme activity in the electrophoresis tubes was revealed by the procedure described by Martín \& Burgos (1982) except for (a) pH of the incubation buffer, 6.4 , and (b) NADH concentration in the incubation mixture, 3 mM.

SDS/polyacrylamide-gel electrophoresis was carried out by the Weber \& Osborn (1969) method. In order to prevent artifacts that would otherwise be produced as a result of carbamoylation of the enzyme protein, urea preparations (Merck, analytical grade) were twice recrystallized immediately before use, by the procedure described by Vogel (1964).

\section{Enzyme purification}

Step 1. After $28-30 \mathrm{~h}$ of incubation, at $30^{\circ} \mathrm{C}, 18 \mathrm{~g}$ of cells was collected by centrifugation (1000 $\mathrm{g}$ for $10 \mathrm{~min})$, suspended in distilled water and centrifuged again, as before, at room temperature. All subsequent operations were performed at $0-5^{\circ} \mathrm{C}$.

The cells were resuspended in $54 \mathrm{ml}$ of $25 \mathrm{~mm}$ $\mathrm{Na}_{2} \mathrm{HPO}_{4} / \mathrm{KH}_{2} \mathrm{PO}_{4}$ buffer, $\mathrm{pH} \mathrm{6.4}$, and homogenized in a Braun MSK Ballotini mill (three treatments of $25 \mathrm{~s}$, at $4000 \mathrm{rev} . / \mathrm{min}$, with glass beads $0.45-0.5 \mathrm{~mm}$ in diameter). The homogenate was centrifuged at $18000 \mathrm{~g}$ for $20 \mathrm{~min}$.

Step 2. The supernatant was chromatographed on a DE-52 DEAE-cellulose column $(1 \mathrm{~cm} \times 14 \mathrm{~cm})$ equilibrated with the buffer used for the homogenization. The column was washed with $30 \mathrm{ml}$ of the same buffer and eluted with $270 \mathrm{ml}$ of a linear gradient of $25 \mathrm{~mm}-1 \mathrm{M}-$ $\mathrm{Na}_{2} \mathrm{HPO}_{4} / \mathrm{KH}_{2} \mathrm{PO}_{4}$ buffer, $\mathrm{pH} 6.4$, at a rate of $55 \mathrm{ml} / \mathrm{h}$; $4 \mathrm{ml}$ fractions were collected. The maximum activity in the eluate appeared in tube 5.

Step 3. The three most active fractions of step 2 were freeze-dried and redissolved in $1.2 \mathrm{ml}$ of distilled water. The solution was chromatographed on a Sephadex G200 column $(1.5 \mathrm{~cm} \times 49 \mathrm{~cm})$ equilibrated and eluted with $7.5 \mathrm{~mm}$-cysteine in $25 \mathrm{~mm}-\mathrm{Na}_{2} \mathrm{HPO}_{4} / \mathrm{KH}_{2} \mathrm{PO}_{4}$ buffer, pH 6.4; $1.5 \mathrm{ml}$ fractions were collected. The peak of activity appeared around tube 35 .

Step 4. The five most active fractions were combined and chromatographed on a hydroxyapatite column $(1 \mathrm{~cm} \times 8 \mathrm{~cm})$ equilibrated with $25 \mathrm{mM}-\mathrm{Na}_{2} \mathrm{HPO}_{4} /$ $\mathrm{KH}_{2} \mathrm{PO}_{4}$ buffer, $\mathrm{pH}$ 6.4. The column was washed with $12 \mathrm{ml}$ of the buffer and eluted with a linear gradient of

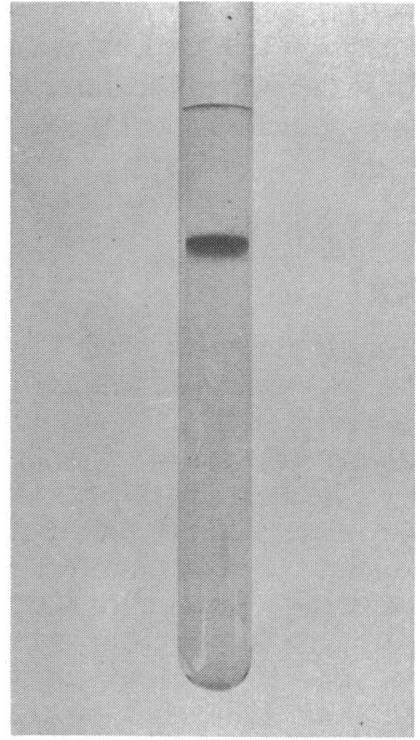

Fig. 1. Polyacrylamide-gel electrophoresis of an enzyme B preparation, with staining for protein

One band of $R_{F} 0.304$ is obtained. Gels stained for diacetyl reductase activity give also one band only with the same $R_{F}$.

25-300 mM- $\mathrm{Na}_{2} \mathrm{HPO}_{4} / \mathrm{KH}_{2} \mathrm{PO}_{4}$ buffer, pH $6.4(100 \mathrm{ml}$ of each one), at $25 \mathrm{ml} / \mathrm{h} ; 3 \mathrm{ml}$ fractions were collected. Two bands of activity appeared in the eluate, the first one (enzyme $A$, Table 1) reaching a maximum around tube 21 and the second one (enzyme B) around tubes 41-42.

The preparations so obtained can be kept at $-18^{\circ} \mathrm{C}$ for several weeks without a noticeable loss in activity.

\section{RESULTS}

\section{Purification}

Table 1 shows the results of a typical purification experiment. Enzyme B was obtained with a specific activity of 42 units/mg of protein and enzyme $A$ with a specific activity of about 8 units/mg (a value of 14 units/ mg was obtained in one of the experiments). The theoretical purification factors were 84-fold and 16-fold respectively, but the real ones should be about twice these values since each enzyme is responsible for approx. $50 \%$ of the diacetyl reductase activity in crude extracts. 
Table 2. Substrate specificity of diacetyl-reducing enzymes from Staph. aureus and of lactate dehydrogenase from Staph. epidermidis

\begin{tabular}{|c|c|c|c|}
\hline \multirow[b]{2}{*}{ Substrate } & \multicolumn{3}{|c|}{$\begin{array}{c}\text { Activity (\% of activity with the best } \\
\text { substrate) }\end{array}$} \\
\hline & Enzyme B & Enzyme & $\begin{array}{l}\text { Lactate } \\
\text { drogenase }^{*}\end{array}$ \\
\hline \multicolumn{4}{|c|}{ Monoaldehydes/ketones } \\
\hline Acetaldehyde & 0 & 17.0 & 0 \\
\hline Hexanal & 0 & 2.5 & 0 \\
\hline Pentan-3-one & 0 & 0 & 0 \\
\hline Butan-2-one & 0 & 0 & 0 \\
\hline Acetone & 0 & 0 & 0 \\
\hline \multicolumn{4}{|c|}{ Uncharged $\alpha$-dicarbonyls } \\
\hline Glyoxal & 0 & 3.6 & 1.5 \\
\hline Methylglyoxal & 0 & 19.4 & 17.0 \\
\hline Diacetyl & 86.9 & 7.9 & 3.5 \\
\hline Methyl pyruvate & 22.8 & 100.0 & 100.0 \\
\hline Pentane-2,3-dione & 100.0 & 28.8 & 10.8 \\
\hline Ethyl pyruvate & 38.4 & 72.7 & 30.5 \\
\hline \multicolumn{4}{|l|}{ Charged $\alpha$-dicarbonyls } \\
\hline Glyoxylic acid & 0 & 56.9 & 27.9 \\
\hline Pyruvic acid & 0 & 83.6 & 90.2 \\
\hline 2-Oxoglutaric acid & 0 & 0 & 0 \\
\hline \multicolumn{4}{|c|}{ Non-vicinal dicarbonyls } \\
\hline Acetylacetone & 0 & 0 & 0 \\
\hline Hexane-2,5-dione & 0 & 9.9 & 1 \\
\hline Ethyl acetoacetate & 0 & 0 & 0 \\
\hline \multicolumn{4}{|l|}{$\alpha$-Hydroxycarbonyls } \\
\hline Glycolaldehyde & 0 & 10.4 & 0 \\
\hline Glyceraldehyde & 0 & 0 & 0 \\
\hline Acetoin & 0 & 0 & 0 \\
\hline
\end{tabular}

* A commercial preparation from Sigma Chemical Co.

\section{Electrophoresis of the purified preparations}

Polyacrylamide-gel electrophoresis of enzyme A preparations showed a main band $\left(R_{F} 0.41\right)$ that coincided with the one observed when gels were stained for activity and three minor ones. Its purity was estimated to be about $50 \%$, as the samples with a specific activity of 14 units/mg gave only one band.

Enzyme B preparations gave a single band of both protein and activity (Fig. 1), with $R_{F} 0.304$ [S.D. \pm 0.006 $(n=4)]$.

\section{Characterization of enzyme B}

The stoichiometry of the reaction catalysed by enzyme B was studied by incubating at $25^{\circ} \mathrm{C}$ the following reaction mixture: enzyme preparation (step 4, Table 1), 7.5 units; NADH, $116 \mu \mathrm{mol}$; diacetyl, $66 \mu \mathrm{mol}$; $25 \mathrm{~mm}$ $\mathrm{NaH}_{2} \mathrm{PO}_{4} / \mathrm{KH}_{2} \mathrm{PO}_{4}$ buffer, pH 6.4, $12 \mathrm{ml}$. After $60 \mathrm{~min}$ of incubation, $64.4 \mu \mathrm{mol}$ of acetoin was obtained, $64.7 \mu \mathrm{mol}$ of diacetyl was reduced and a similar quantity of NADH $(62.8 \mu \mathrm{mol})$ was oxidized.

This enzyme turned out to be specific for $\beta$-NADH (the usual form): no activity was detected with NADPH or $\alpha$-NADH. It accepted as substrates all uncharged $\alpha-$ dicarbonyls with more than three carbon atoms tested (Table 2). $\alpha$-Diketones (diacetyl and pentane-2,3-dione) were the most effectively used compounds. It also reduced $\alpha$-oxo acid esters (ethyl pyruvate and methyl pyruvate), but with a lower activity. A single enzyme catalyses the four reactions: (a) activity tests with 13.3 mM-diacetyl and $13.3 \mathrm{~mm}$-methyl pyruvate mixtures showed values lying between those obtained with each of these substrates separately at a $13.3 \mathrm{~mm}$ concentration; similar experiments with diacetyl and pentane-2,3-dione and with diacetyl and ethyl pyruvate gave the same result; $(b)$ the same $R_{F}$ in polyacrylamide-gel electrophoresis [0.303, S.D. $\pm 0.005(n=8)]$ was obtained when the gels were stained for diacetyl reductase, pentanedione reductase, methyl pyruvate reductase or ethyl pyruvate reductase activities; $(c)$ hydroxyapatite chromatography showed parallel elution profiles for the four activities.

The reduction products of the $\alpha$-dicarbonyls have stereoisomers. Enzyme B stereospecificity was studied by incubating, at $20^{\circ} \mathrm{C}, 77 \mu \mathrm{mol}$ of $\mathrm{NADH}, 140 \mu \mathrm{mol}$ of diacetyl and 2 units of a pure preparation of enzyme $\mathrm{B}$ in $8 \mathrm{ml}$ of $0.2 \mathrm{M}-\mathrm{Na}_{2} \mathrm{HPO}_{4} / \mathrm{KH}_{2} \mathrm{PO}_{4}$ buffer, $\mathrm{pH}$ 7. The acetoin produced was the $\mathrm{L}(+)$ form, with $[\alpha]_{\mathrm{D}}^{20}+249.1^{\circ}$ [S.D. $\left.\pm 28^{\circ}(n=9)\right](c=0.07 \mathrm{~g} / 100 \mathrm{ml})$. This value is similar to that obtained by other authors for L-acetoin produced by enzymic reduction of diacetyl (Bernardo et al., 1981; Provecho et al., 1984).

\section{Properties of enzyme B}

Enzyme B action is, for practical purposes, irreversible : no activity was detected in the dehydrogenase direction with acetoin and ethyl lactate at concentrations ranging from $2.5 \mathrm{~mm}$ to $330 \mathrm{~mm}$, even at $\mathrm{NAD}^{+}$concentrations up to $5 \mathrm{~mm}$. 


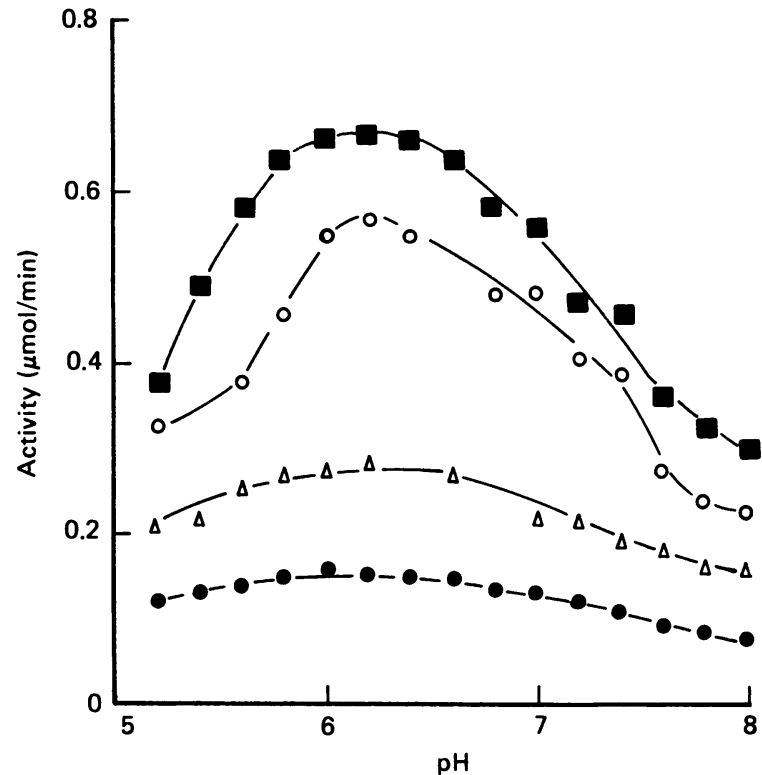

Fig. 2. pH-activity profiles of the reactions catalysed by enzyme $B$ in $0.1 \mathrm{M}-\mathrm{Na}_{2} \mathrm{HPO}_{4} / \mathrm{KH}_{2} \mathrm{PO}_{4}$ buffer

a, Pentane-2,3-dione reductase; $O$, diacetyl reductase; $\triangle$, ethyl pyruvate reductase; $O$, methyl pyruvate reductase. The standard concentrations of substrate and coenzyme (Strecker \& Harary, 1954) were used.

Fig. 2 presents the $\mathrm{pH}$-activity profiles for the reduction of diacetyl, pentane-2,3-dione, ethyl pyruvate and methyl pyruvate under the standard assay conditions. The optimum $\mathrm{pH}$ for the enzyme was about 6 .

Table 3 summarizes the apparent values obtained for $V_{\max }$ and $K_{\mathrm{m}}$ in the reduction of the compounds accepted by enzyme $B$. In these experiments substrate inhibition was observed with diacetyl, ethyl pyruvate and methyl pyruvate at concentrations above $80-90 \mathrm{~mm}$. With pentane-2,3-dione no inhibition appeared at concentrations up to $200 \mathrm{mM}$.

The $M_{\mathrm{r}}$ of enzyme B was estimated to be 68000 by Sephadex G-200 chromatography (reference proteins : $\gamma$ globulin, $M_{\mathrm{r}} 160000$; serum albumin, $M_{\mathrm{r}} 66500$; myoglobin, $M_{\mathrm{r}} 17000$; cytochrome $\left.c, M_{\mathrm{r}} 12500\right)$. A similar value was obtained by SDS/polyacrylamide-gel electrophoresis after incubating the samples for $2 \mathrm{~h}$ at $37^{\circ} \mathrm{C}$ in a solution of SDS $(1 \%), 2$-mercaptoethanol $(1 \%)$ and urea $(0,3,8$ or $12 \mathrm{M})$ in $10 \mathrm{~mm}$-sodium phosphate buffer, pH 7 (standard proteins: serum albumin, egg albumin, myoglobin, $\alpha$-lactalbumin and $\alpha$-chymotrypsin, whose $M_{\mathrm{r}}$ values were taken from Weber \& Osborn, 1969). This suggests that enzyme $B$ is a monomer.

\section{Characterization of enzyme $A$}

Enzyme A also proved to be specific for $\beta$-NADH and did not accept as coenzyme either NADPH or $\alpha$-NADH. Table 2 shows its substrate specificity. The most effectively reduced compounds were pyruvate and its ethyl and methyl esters. Diacetyl turned out to be a very poor substrate. Polyacrylamide-gel electrophoresis of a purified preparation of enzyme A with staining of the gels for diacetyl reductase, pyruvate reductase and methyl pyruvate reductase activities gave, in each case, one single band with $R_{F} 0.41$ [S.D. $\pm 0.004(n=6)$ ]. Assays with mixtures of diacetyl and pyruvate (13.3 mM each) yielded higher reaction rates than those obtained with $13.3 \mathrm{~mm}$-diacetyl and lower than those observed with 13.3 mM-pyruvate. The same happened when the experiments were carried out with mixtures of diacetyl and one of the following compounds: methyl pyruvate, ethyl pyruvate, glyoxylic acid, pentane-2,3-dione, methylglyoxal, acetaldehyde and glycolaldehyde.

Enzyme A specificity is similar to that obtained with a commercial preparation of lactate dehydrogenase from Staph. epidermidis (Table 2), except for the slight activity shown with acetaldehyde and glycolaldehyde by our enzyme. On the other hand, polyacrylamide-gel electrophoresis of the dehydrogenase from Staph. epidermidis also gave $R_{F} 0.41$ when the gels were stained for enzyme activity.

Therefore we conclude that enzyme $\mathrm{A}$ is a lactate dehydrogenase. This enzyme has not been further studied, since it remains outside the scope of the present paper.

\section{DISCUSSION}

\section{Purification}

The purification procedure outlined here is clearly better than the one by Strecker \& Harary (1954) as: (a)

\section{Table 3. Substrate and coenzyme affinity of enzyme B}

To obtain $V_{\text {max.(app.) }}$ and $K_{\text {m(app.) }}$ for the carbonyl substrates, assays were performed at 0.2 mM-NADH. A fixed concentration of $50 \mathrm{~mm}$ of the carbonyl was used to estimate the apparent values of $V_{\max .}$ and $K_{\mathrm{m}}$ for NADH.

\begin{tabular}{|c|c|c|c|c|}
\hline Reaction & $\begin{array}{l}\text { Varied-concentration } \\
\text { substrate }\end{array}$ & $K_{\mathrm{m}(\mathrm{app} .)}(\mathrm{mM})$ & $\begin{array}{c}V_{\max .(a p p .)} \\
(\mu \mathrm{mol} / \mathrm{min} \text { per } \\
\text { unit of enzyme) }\end{array}$ & $K_{\mathrm{i}}^{*}(\mathrm{mM})$ \\
\hline Diacetyl reductase & $\begin{array}{l}\text { Diacetyl } \\
\text { NADH }\end{array}$ & $\begin{array}{l}15 \\
0.045\end{array}$ & $\begin{array}{l}2.3 \\
2.2\end{array}$ & $\begin{array}{c}300 \\
-\end{array}$ \\
\hline Pentane-2,3-dione reductase & $\begin{array}{l}\text { Pentane-2,3-dione } \\
\text { NADH }\end{array}$ & $\begin{array}{l}6 \\
0.025\end{array}$ & $\begin{array}{l}2.0 \\
2.1\end{array}$ & $\begin{array}{l}- \\
-\end{array}$ \\
\hline Ethyl pyruvate reductase & $\begin{array}{l}\text { Ethyl pyruvate } \\
\text { NADH }\end{array}$ & $\begin{array}{l}24 \\
0.110\end{array}$ & $\begin{array}{l}1.6 \\
1.6\end{array}$ & 150 \\
\hline Methyl pyruvate reductase & $\begin{array}{l}\text { Methyl pyruvate } \\
\text { NADH }\end{array}$ & $\begin{array}{l}16 \\
0.095\end{array}$ & $\begin{array}{l}0.7 \\
0.8\end{array}$ & $\begin{array}{c}150 \\
-\end{array}$ \\
\hline
\end{tabular}

* Diacetyl, ethyl pyruvate and methyl pyruvate produced substrate inhibition at concentrations higher than 80 mM. No inhibition by pentane-2,3-dione was observed in the range studied (up to $200 \mathrm{~mm}$ ). 
it employs techniques that are less damaging to the enzyme; (b) it removes from purified preparations a lactate dehydrogenase that uses diacetyl, albeit poorly; (c) it yields electrophoretically pure samples of the reductase, which efficiently accepts diacetyl, its specific activity being about 10 times that achieved by the aforementioned authors' method.

\section{pH-activity profiles and affinity for the coenzyme and substrates}

$K_{\mathrm{m}}$ values for the carbonyl substrate between 1.2 and $30 \mathrm{mM}$ and for NADH between $4 \mu \mathrm{M}$ and $0.14 \mathrm{~mm}$ have been reported for NAD-specific enzymes that reduce diacetyl (Branen \& Keenan, 1970; Johansen et al., 1973; Larsen et al., 1973; Louis-Eugene et al., 1984). Our data for enzyme $B$ remain in an intermediate position between these values. The $\mathrm{pH}$-activity profiles obtained by us, with an optimum value of around $\mathrm{pH} 6$, also agree with those reported for other enzymes metabolically related to the one studied here (Gabriel et al., 1971; Burgos \& Martin, 1972; Diez et al., 1974; Silber et al., 1974).

Our kinetic data show that, at least in vitro, diacetyl is not the best substrate for enzyme B, pentane-2,3-dione being reduced more effectively. The $V_{\max }$ values estimated for the reduction of both compounds were very similar, but $K_{\mathrm{m}}$ values for NADH and for the carbonyl were about twice as high with diacetyl as with pentane2,3-dione. On the other hand, no substrate inhibition was observed with the latter compound even at $16 \times K_{\mathrm{m}}$, whereas it appears at $5 \times K_{\mathrm{m}}$ with diacetyl.

\section{Nomenclature of the diacetyl-reducing enzymes}

Most of the groups who have isolated enzymes capable of reducing diacetyl did not carry out systematic studies of specificity and stereospecificity. Consequently, great uncertainty exists concerning the nomenclature of these oxidoreductzses.

Only two of these enzymes have been properly characterized. One is L-glycol dehydrogenase [L-glycol: NAD $(\mathrm{P})^{+}$oxidoreductase, EC 1.1.1.185) from hen muscle and bovine liver (Bernardo et al., 1981; Burgos \& Martin, 1982; Provecho et al., 1984). It is a monomer of $M_{\mathrm{r}} 28000-30000$ that reduces $\alpha$-dicarbonyls to $\mathrm{L}-\alpha-$ hydroxycarbonyls and these to L-glycols, using as coenzyme ether NADH or NADPH. The other is $\alpha$-dicarbonyl reductase [L- $\alpha$-hydroxycarbonyl: $\mathrm{NAD}(\mathrm{P})^{+}$ oxidoreductase, EC 1.1.1.-) from bovine and pigeon liver (Provecho et al., 1984; Bernardo et al., 1984). It is an oligomer of $25000-26000-M_{r}$ subunits. It reduces, irreversibly in practice, uncharged $\alpha$-dicarbonyls with more than three carbon atoms to $\mathrm{L}-\alpha$-hydroxycarbonyls, with either NADH or NADPH as coenzyme.

Other diacetyl-reducing enzymes that have been isolated are not so well defined. The group headed by Dr. Stormer purified one from Aerobacter aerogenes, which they called diacetyl (acetoin) reductase. This enzyme reduces diacetyl, pentane-2,3-dione, acetoin and acetylethylcarbinol and is specific for NADH (Bryn et al., 1971 ; Larsen et al., 1973); it is a tetramer of $M_{\mathrm{r}} 100000$ (Hetland et al., 1971). Enzymes with similar properties have been obtained from Klebsiella pneumoniae (Shimizu et al., 1977) and from Saccharomyces uvarum (LouisEugene et al., 1984). A more thorough specificity study and the verification of the steric form of its products is required for a definitive characterization. Silber et al.
(1974) have partially purified a different enzyme from Escherichia coli, capable of reducing diacetyl and other $\alpha$-dicarbonyls, that they describe as specific for NADPH, although, according to the data of these authors, NADH could also be used; its $M_{\mathrm{r}}$ was estimated to be 10000 . There are not enough data available to enable a final identification. Another enzyme has also been described, from Sacch. uvarum, that appears to reduce diacetyl and acetoin and is specific for NADPH (Van den Berg et al., 1983). It has not as yet been characterized further. Finally, it has been proved that NAD-dependent alcohol dehydrogenase can reduce diacetyl in vitro (Juni \& Heym, 1957; Van den Berg et al., 1983), and in the present paper we demonstrate that lactate dehydrogenases from Staph. epidermidis and Staph. aureus can also do this. It is unlikely that any of these dehydrogenases operates with diacetyl in the cell, since the activity with this compound is very low (around $5 \%$ of that obtained with its best substrate). However, the possibility that some of the enzymes considered as diacetyl reductases are, in fact, lactate dehydrogenases or alcohol dehydrogenases should not be ruled out.

It can be deduced from our results that enzyme B: (a) reduces (irreversibly for practical purposes) $\alpha$-diketones and all types of uncharged $\alpha$-dicarbonyls with more than three carbon atoms; $(b)$ is specific for NAD; $(c)$ does not accept monoaldehydes or pyruvate; $(d)$ has an $M_{\mathrm{r}}$ of 68000 and is not dissociated by SDS and 2-mercaptoethanol even in the presence of urea up to $12 \mathrm{M}$. These properties are clearly different from those of all other enzymes capable of reducing diacetyl. $\alpha$-Dicarbonyl reductase from animal tissues shows the same substrate specificity, but it operates basically with NADPH, although it can also use NADH (Provecho et al., 1984; Bernardo et al., 1984, 1985). Furthermore, this enzyme is formed of $25000-26000-M_{\mathrm{r}}$ subunits and also differs from the one studied in the present work in electrophoretic mobility: the reductase from Staph. aureus shows $R_{F} 0.303$ in acrylamide-gel electrophoresis; that from pigeon and bovine liver gives, under the same operation conditions (Provecho et al., 1984), $R_{F}$ about 0.18 (Provecho et al., 1984; Bernardo et al., 1984).

Therefore enzyme B cannot be included in any of the groups of diacetyl-reducing enzymes hitherto described. Three names could be appropriate for this enzyme, as follows. (a) $\alpha$-Dicarbonyl reductase (NAD): this name describes its functions quite well, but does not indicate that it does not accept charged $\alpha$-dicarbonyls, such as pyruvate, or two uncharged $\alpha$-dicarbonyls of physiological interest, namely glyoxal and methylglyoxal. (b) $\alpha$ Diketone reductase (NAD): this name correctly defines its primary substrates, which, furthermore, seem to be metabolized through the same pathways (Larsen et al., 1973); although this name does not cover the reduction of $\alpha$-oxo acid esters, it must be taken into account that they are worse substrates than diketones and are of hardly any physiological significance. (c) Diacetyl reductase: this has the advantage of retaining a name that is in common use; however, it suggests that the enzyme is primarily specific for diacetyl and does not account for pentane-2,3-dione being a substrate at least as good as diacetyl. As far as we know, the existence of an enzyme that deserves the name of diacetyl reductase has never been proved: none of those whose specificity has been well studied shows a clear priority for diacetyl over other alternative substrates. In our opinion, this name should 
be removed from the I.U.B. Enzyme Nomenclature list.

We suggest the recommended name ' $\alpha$-diketone reductase (NAD)' and the systematic name ' $L-\alpha$-hydroxyketone: $\mathrm{NAD}^{+}$oxidoreductase' for enzyme $\mathrm{B}$. We also postulate that it be classified with the number EC 1.1.1.5, which diacetyl reductase takes up at present.

The arguments in favour of this terminology are also valid for the bovine and pigeon liver enzyme. We propose the name ' $\alpha$-diketone reductase [ $L-\alpha$-hydroxyketone: $\mathrm{NAD}(\mathrm{P})^{+}$oxidoreductase]' for it, instead of its former name of $\alpha$-dicarbonyl reductase, which had been put forward by our group.

This work was supported by a grant from the Comision Asesora de Investigación Científica y Técnica (Project no. $1069 / 81)$.

\section{REFERENCES}

Bernardo, A., Burgos, J. \& Martín, R. (1981) Biochim. Biophys. Acta 659, 189-198

Bernardo, A., González, J. \& Martín, R. (1984) Int. J. Biochem. 16, 1065-1070

Bernardo, A., Martín, R., Vidal, I. \& González, J. (1985) Int. J. Biochem. 17, 265-269

Branen, A. L. \& Keenan, T. W. (1970) Can. J. Microbiol. 16, 947-951

Bryn, K., Hetland, O. \& Stormer, F. C. (1971) Eur. J. Biochem. 18, 116-119

Burgos, J. \& Martín, R. (1972) Biochim. Biophys. Acta 268, 261-270

Burgos, J. \& Martín, R. (1982) Methods Enzymol. 89, 523-526
Chance, B. \& Redfearn, E. R. (1961) Biochem. J. 80, 632-640

Diez, V., Burgos, J. \& Martín, R. (1974) Biochim. Biophys. Acta 350, 253-262

Fenner, C., Traut, R. R., Mason, D. T. \& Wikman-Coffelt, J. (1974) Anal. Biochem. 63, 595-602

Fuertes, J., Bernardo, A., Burgos, J. \& Martín, R. (1977) An. Fac. Vet. León 23, 127-134

Gabriel, M. A., Jabara, H. \& Al-Khalidi, U. A. S. (1971) Biochem. J. 124, 793-800

Hetland, O., Olsen, B. R., Christenssen, T. B. \& Stormer, F. C. (1971) Eur. J. Biochem. 20, 200-205

Johansen, L., Larsen, S. H. \& Stormer, F. C. (1973) Eur. J. Biochem. 34, 97-99

Juni, E. \& Heym, G. (1957) J. Bacteriol. 74, 757-767

Larsen, S. H., Johansen, L. \& Stormer, F. C. (1973) FEBS Lett. 31, 39-41

Louis-Eugene, S., Ratomahenina, R. \& Galzy, P. (1984) Z. Allg. Mikrobiol. 24, 151-159

Martín, R. \& Burgos, J. (1982) Methods Enzymol. 89, 516-523

Pack, M. Y., Sandine, W. E., Elliker, P. R., Day, E. A. \& Lindsay, R. C. (1964) J. Dairy Sci. 47, 981-986

Provecho, F., Burgos, J. \& Martín, R. (1984) Int. J. Biochem. 16, 423-427

Shimizu, H., Hanaichi, Y., Okada, A. \& Tomoyeda, M. (1977) Agric. Biol. Chem. 41, 527-532

Silber, P., Chung, H., Gargiulo, P. \& Schulz, H. (1974) J. Bacteriol. 118, 919-927

Strecker, H. J. \& Harary, I. (1954) J. Biol. Chem. 211, 263-270

Strecker, H. J. \& Ochoa, S. (1954) J. Biol. Chem. 209, 313-326

Van den Berg, R., Harteveld, P. A. \& Martens, F. B. (1983) Proc. Congr. Eur. Brew. Conv. 19th 497-504

Vogel, A. I. (1964) Practical Organic Chemistry, 3rd edn., p. 441, Longmans, London

Warburg, O. \& Christian, W. (1941) Biochem. Z. 310, 384-395

Weber, K. \& Osborn, M. (1969) J. Biol. Chem. 244, 4406-4412 